\title{
Hypertension bearers with high risk/big risk of cardiovascular diseases and socioeconomic and health indicators
}

\author{
Simone de Melo Costa ${ }^{1}$ \\ (iD) Cássio de Almeida Lima² \\ André Luiz Cândido Sarmento Drumond Nobre ${ }^{3}$ \\ Davi de Melo Alvarenga Vieira ${ }^{4}$ \\ André Luiz Ramos Leal'
}

\begin{abstract}
1. Doctor, Department of Dentistry, State University of Montes Claros, Montes Claros, MG, Brasil. 2. Master, Postgraduate Program of Healthcare, Society and Environment, Federal University of the Jequitinhonha and Mucuri, Diamantina, MG, Brasil. 3. Master, State Specialized Care Centre, Brasília de Minas, MG, Brasil. 4. Academic, Medicine Graduation Course, Valença Higher Education Centre, Valença, RJ, Brasil.
\end{abstract}

http://dx.doi.org/10.1590/1806-9282.64.07.601

\section{SUMMARY}

OBJECTIVE: To correlate the number of hypertensive patients with high and very high risk for cardiovascular diseases with socioeconomic and health indicators.

METHODS: An ecological study carried out from the National Registry of Hypertension and Diabetes (SisHiperDia). The variable "hypertensive patients with high and very high risk" was correlated with the Human Development Index, health care costs and services, average household income per capita, per capita municipal income, number of hospital admissions in SUS, number of medical consultations in the SUS and specific mortality due to diseases of the circulatory system, considering the 27 federative units of Brazil. The data was processed in software IBM Statistical Package for the Social Sciences (SPSS) Statistics, version 22.0O. The statistical analysis considered the level of significance $p<0.05$.

RESULTS: Brazilian states with more hypertensive registries in high/very high risk spend more on public health, fewer people reach the elderly age group and more deaths from diseases of the circulatory system $(p<0.05)$. The very high risk stratum correlated with more physicians per population $(p<0.05)$.

CONCLUSION: Systemic arterial hypertension has a direct impact on life expectancy and also on the economic context, since when it evolves to high and very high risk for cardiovascular diseases, it generates more expenses in health and demand more professionals, burdening the public health system. Monitoring is necessary in order to consolidate public policies to promote the health of hypertensive individuals.

KEYWORDS: Hypertension. Public health. Brazil. Economic indexes. Social indicators.

\section{INTRODUCTION}

Chronic Non-communicable Diseases (NCDs) are the leading cause of death in the world, accounting for a high number of premature deaths. They compromise quality of life, with a high degree of limitation in work and leisure activities, generate economic impacts for families, communities and society in general, as well as aggravate social and health inequities. Approximately $80 \%$ of NCD deaths occur in low and middle-income countries. In Brazil, NCDs represent the greatest health problem and correspond to $72 \%$ of the causes of death, affecting especially the poor population and vulnerable groups'.

Among the main NCDs is Systemic Arterial Hypertension (SAH), a serious global public health prob$\mathrm{lem}^{2}$. SAH is an independent risk factor for cardiovascular diseases ${ }^{3}$. This condition is characterized by

DATE OF SUBMISSION: 11-Nov-2017

DATE OF ACCEPTANCE: $14-$ Dec-2017

CORRESPONDING AUTHOR: Cássio de Almeida Lima

Universidade Federal dos Vales do Jequitinhonha e Mucuri. Rodovia MGT 367 - Km 583, no 5000

Alto da Jacuba - CEP 39100-000 - Diamantina, MG - Brasil

Tel: (38) 992460602

E-mail: cassioenf2014@gmail.com

smelocosta@gmail.com andreluiznobre@hotmail.com davimelo_93@hotmail.com andreluiz_rl@hotmail.com 
a slow and asymptomatic clinical course, high prevalence, multiple risk factors and control difficulties. When not properly treated, SAH may cause complications in the cardiovascular system ${ }^{4-7}$.

It is estimated that one in three adults has $\mathrm{SAH}$, which is equivalent to approximately 1 billion people in the world. As a consequence, there are 9.4 million annual deaths from cardiovascular diseases ${ }^{5}$. At the national level, since the 1960s, the SAH complications have emerged as the main cause of death ${ }^{4,7}$. Average prevalence of self-reported SAH in the population above 18 years of age is $22.7 \%$, being higher in women $(25.4 \%)$ than in men (19.5\%) ${ }^{6}$.

Thus, it is necessary to provide appropriate healthcare to the hypertensive. Therefore, stratifying cardiovascular risk can be an effective strategy to plan the most qualified care, depending on the situation of each patient, contributing to reduce the negative repercussions of the disease development. The classification in risk levels allows estimating the probability of developing major cardiovascular events, such as vascular death, myocardial infarction and cerebrovascular accident. This estimate is based on the presence of multiple risk factors, such as gender, age, blood pressure levels, smoking, and cholesterol levels. From the low, moderate, high and very high risk stratification, individuals with a higher chance of complications are selected so that they can benefit from more appropriate interventions ${ }^{2}$.

In individuals with high or very high risk, factors such as being more prone to a cardiovascular event; presence of diabetes mellitus or target organ damage such as acute myocardial infarction, cerebrovascular accident/transient ischemic attack, left ventricular hypertrophy, retinopathy and nephropathy are taken into account. Follow-up of hypertensive patients classified in these strata should be judicious, with guidelines on healthy lifestyle and collective activities of healthcare education ${ }^{2}$.

Effective care, including cardiovascular risk stratification, is undoubtedly relevant, considering the high morbidity and mortality of SAH, especially deaths caused by cerebrovascular diseases ${ }^{7}$. Therefore, this disease implies considerable impacts for the healthcare sector and society. Its social importance is evidenced, which demonstrates the need to understand the relationship with social, economic factors and health indicators. However, in this context, there are gaps in knowledge, which means the specificities of the subject in question regarding its interface with the social characteristics of the country are now known. And the lack of information about the comprehensiveness, complexity and social, economic and political interrelations of SAH makes it difficult to act on the problem ${ }^{7-9}$. It is of fundamental importance to investigate the relationship between high/very high cardiovascular risk strata and socioeconomic and health indicators, considering that these strata are the most unfavourable and have the largest impact on public health.

In this sense, the studies should describe more clearly the determining factors of the pathology in question, according to a set of sociocultural, economic and geographical characteristics ${ }^{8,9}$. It is expected that knowledge can assist healthcare managers in the challenge of creating and implementing public policies that are consistent with reality, capable of reducing inequalities, quantitatively improving healthcare infrastructure, and making public health universal $^{10}$.

The purpose of this study was to correlate the number of hypertensive patients at high and very high risk for cardiovascular diseases with the socioeconomic and health indicators of the Brazilian federative units.

\section{METHODS}

This is an ecological, multi-group study, carried out from the unit of analysis "registries of hypertensive stratified at high and very high risk for cardiovascular diseases" of the National System of Registry of Hypertension and Diabetes (SisHiperDia). The data from SisHiperDia were collected through the website of the Department of Informatics of the Brazilian National Health System (DataSUS), in August 2013. The System processes information on patients with SAH and diabetes mellitus, registered in healthcare units or Basic Care teams of the Brazilian National Health System (SUS) ${ }^{11}$.

The classification adopted by the Brazilian Ministry of Health in SisHiperDia represents the result of the stratified risk calculation, identified and broken down according to four levels of stratification, presented in Chart 1. ${ }^{11}$

The variable "hypertensive with high and very high risk" was correlated with the Human Development Index (HDI), expenditures with healthcare actions and services, average household income per capita, municipal income per capita, number of hos- 
CHART 1. DESCRIPTION OF THE RISK CLASSIFICATION ADOPTED IN THE NATIONAL REGISTRY SYSTEM OF HYPERTENSION AND DIABETES (SISHIPERDIA).

\begin{tabular}{|c|c|c|c|}
\hline \multicolumn{4}{|c|}{ Stratified risk and quantification of blood pressure prognosis $(\mathrm{mmHg})$} \\
\hline Risk factors or disease & $\begin{array}{l}\text { Grade } 1 \\
\text { Mild hypertension } \\
\text { SBP }^{*} 140-159 \text { or DBP ** } \\
90-99\end{array}$ & $\begin{array}{l}\text { Grade } 2 \\
\text { Moderate hypertension } \\
\mathrm{SBP}^{*} 160-179 \text { or DBP ** } \\
100-109\end{array}$ & $\begin{array}{l}\text { Grade } 3 \\
\text { Severe hypertension } \\
\mathrm{SBP}^{*} \geq 180 \text { or } \mathrm{DBP}{ }^{* *} \geq 110\end{array}$ \\
\hline I- No other risk factors. & Low risk & Average risk & High risk \\
\hline II- One to two risk factors. & Average risk & Average risk & Very high risk \\
\hline $\begin{array}{l}\text { III- Three or more risk factors, or lesions in the target } \\
\text { organs, or diabetes mellitus. }\end{array}$ & High risk & High risk & Very high risk \\
\hline $\begin{array}{l}\text { IV - Associated clinical conditions, including cardio- } \\
\text { vascular or renal disease. }\end{array}$ & Very high risk & Very high risk & Very high risk \\
\hline
\end{tabular}

pitalizations in SUS, number of consultations in the SUS and of medical professionals, and specific mortality due to coronary artery disease (CAD). It considered the records and socioeconomic and health indicators of the 27 federative units (UF) of Brazil grouped into five regions: North, Northeast, Southeast, South and Mid-West.

The HDI of each state, as well as its HDI education and HDI income strata, were collected from the Atlas of Human Development in Brazil, an electronic database developed by the United Nations Development Program (UNDP) ${ }^{12}$ from national censuses. The HDI measures the level of human development in the countries and covers three dimensions: education, longevity and municipal income per capita. It ranges from 0 (no human development) to 1 (total human development).

Expenditure on public health actions and services, per capita, refers to the value of the total expenditure per federation unit for each individual, in 2010. This data was determined on the website Ministry of Health/Executive Secretariat/Healthcare and Development Economics Area/Information System on Budgets of the Information System on Public Budgets (Siops) ${ }^{13}$.

The average household income, per capita, in 2010, considered the minimum wage at the time, BRL $510.00^{14}$. The municipal income, per capita, indicates the average income of individuals residing in each state, from the Brazilian Institute of Geography and Statistics (IBGE). It adds up all kinds of income obtained by the residents of the municipalities (including salaries, pensions and government transfers, among others), and the sum is divided by the total number of inhabitants of the state ${ }^{15}$.

The number of hospital admissions in SUS per 100 inhabitants in 2010 was obtained from the web- site of the Ministry of Health/DataSUS - SUS Hospital Information System (SIH/SUS). ${ }^{16}$ The source of data on the variable probability of survival up to 60 years was the UNDP (2010) ${ }^{12}$.

The number of medical consultations, in the SUS, per inhabitant, in 2010, was verified on a website of the Ministry of Health/SE/DataSUS - SUS Outpatient Information System (SIA/SUS) for $2010^{17}$. The number of doctors per 1,000 inhabitants, in 2010, followed information from the Ministry of Health/ SGTES/Degerts/Conprof - Professional councils. The variable refers to the ratio between the total number of physicians residing in a given municipality and the total number of inhabitants of the same municipality, multiplied by $1,000^{18}$.

CAD-specific mortality, which represents deaths from diseases of the circulatory system, per 100,000 inhabitants, in 2010, was based on the records of the Mortality Information System (SIM). The values are calculated from deaths reported to SIM and IBGE ${ }^{19}$.

The database was built on the IBM Statistical Package for the Social Sciences (SPSS) Statistics, version $22.0^{\circledR}$. The descriptive analysis considered for each federative unit the total population, the number of hypertensive registries in the system, the percentage of people classified as both high risk and very high risk. The federative units were grouped by Brazilian region (North, Northeast, Southeast, South and Mid-West) and the averaged and medians of registries in SisHiperDia were calculated at high risk and at very high risk. The medians were compared by the Kruskal-Wallism test, according to the Brazilian region. The correlation between socioeconomic and health indicators with high and very high risk hypertensive registries was made according to the Spearman's correlation with correlation coefficient $(r)$ and determination factor $\left(r^{2}\right)$. Non-parametric tests were 
adopted, since the Kolmogorov-Smirnov test presented $p<0.05$. The tests considered the level of significance $\mathrm{p}<0.05$ and the $95 \%$ confidence interval.

The study was developed in accordance with National Health Council Resolution no. 466 of December 12, 2012. It was waived of evaluation from an ethics committee in research involving human beings because it was based exclusively on secondary public domain data, without nominal identification.

\section{RESULTS}

The percentage values referring to the number of individuals with SAH who were stratified at high and very high risk for cardiovascular diseases, in relation to the total number of hypertensive patients registered, by state, are presented in Chart 2 . As for the SAH registries stratified as high-risk, the percentage value in relation to the total number of registries in each Brazilian state ranged from $13.74 \%$ for the state of Tocantins (TO), in the North region, to 22.12\% for the Federal District (DF), in the Mid-West. For the very high risk registries, the percentage values between states varied from $4.91 \%$ to $18.77 \%$, the lowest value for Amazonas (AM) and the highest for Acre (AC), both located in the North region of Brazil. [Chart 2.]

The analysis of the median number of stratified hypertensive patients at high risk per region showed a lower value in the North, 25,897.17, and the highest in the Southeast, $243,308,37$, with a statistically significant difference $(p=0.002)$ among the medians of the five Brazilian regions (Table 1). The median of registries at very high risk was also higher in the South-

CHART 2. REGISTRIES OF SAH AND PERCENTAGES OF HIGH AND VERY HIGH RISK STRATIFICATION PER FEDERATIVE UNIT (UF)

\begin{tabular}{|c|c|c|c|c|c|c|}
\hline Region & UF & $\begin{array}{l}\text { State total popu- } \\
\text { lation }\end{array}$ & $\begin{array}{l}\text { Number of } \\
\text { hypertensive } \\
\text { registries in the } \\
\text { system }\end{array}$ & $\begin{array}{l}\text { High risk } \\
(\%)\end{array}$ & $\begin{array}{l}\text { Very high risk } \\
(\%)\end{array}$ & $\begin{array}{l}\text { Total high/ } \\
\text { very high risk } \\
(\%)\end{array}$ \\
\hline \multirow[t]{7}{*}{ North } & $\mathrm{RO}$ & $1,562,409$ & 115,180 & 14.95 & 17.20 & 32.15 \\
\hline & $A C$ & 733,559 & 43,224 & 15.55 & 18.77 & 34.32 \\
\hline & AM & $3,483,985$ & 282,282 & 15.84 & 4.91 & 20.75 \\
\hline & $\mathrm{RR}$ & 450,479 & 20,383 & 17.29 & 15.30 & 32.59 \\
\hline & PA & $7,581,051$ & 256,888 & 17.55 & 16.25 & 33.80 \\
\hline & $A P$ & 669,526 & 18,218 & 20.29 & 16.28 & 36.57 \\
\hline & $\mathrm{TO}$ & $1,383,445$ & 99,163 & 13.74 & 14.85 & 28.59 \\
\hline \multirow[t]{9}{*}{ Northeast } & MA & $6,574,789$ & 325,570 & 16.17 & 12.95 & 29.12 \\
\hline & $\mathrm{PI}$ & $3,118,360$ & 217,443 & 15.33 & 11.06 & 26.39 \\
\hline & CE & $8,452,381$ & 342,828 & 16.76 & 9.24 & 26.00 \\
\hline & RN & $3,168,027$ & 154.808 & 18.61 & 12.85 & 31.46 \\
\hline & PB & $3,766,528$ & 323,639 & 19.41 & 14.38 & 33.79 \\
\hline & $\mathrm{PE}$ & $8,796,448$ & 400,846 & 18.51 & 12.53 & 31.04 \\
\hline & $\mathrm{AL}$ & $3,120,494$ & 139,660 & 19.51 & 11.52 & 31.03 \\
\hline & SE & $2,068,017$ & 104,283 & 20.46 & 12.36 & 21.82 \\
\hline & BA & $14,016,906$ & 932,831 & 18.15 & 12.01 & 30.16 \\
\hline \multirow[t]{4}{*}{ Southeast } & $M G$ & $19,597,330$ & $1.395,732$ & 15.46 & 14.99 & 30.45 \\
\hline & ES & $3,514,952$ & 297,709 & 17.86 & 15.17 & 33.03 \\
\hline & RJ & $15,989,929$ & 646,829 & 20.36 & 16.10 & 36.46 \\
\hline & $\mathrm{SP}$ & $41,262,199$ & $1,719,462$ & 20.65 & 13.13 & 33.78 \\
\hline \multirow[t]{3}{*}{ South } & PR & $10,444,526$ & 723,455 & 15.48 & 17.46 & 32.94 \\
\hline & SC & $6,248,436$ & 412,357 & 17.01 & 17.86 & 34.87 \\
\hline & RS & $10,693,929$ & 598,461 & 18.78 & 18.16 & 36.94 \\
\hline \multirow[t]{4}{*}{ Mid-West } & MT & $3,035,122$ & 240,928 & 14.65 & 16.78 & 31.43 \\
\hline & MS & $2,449,024$ & 148,405 & 15.44 & 15.80 & 31.24 \\
\hline & $\mathrm{GO}$ & $6,003,788$ & 290,373 & 14.72 & 18.26 & 32.98 \\
\hline & DF & $2,570,160$ & 50,493 & 22.12 & 15.49 & 37.61 \\
\hline
\end{tabular}

Source: Prepared by the authors. 
east region, 181,698,33, and lower in the Midwest, $30,317.53$, with a statistically significant difference $(p=0.003)$ among the Brazilian regions (Table 1).

The correlation between high risk registries and socioeconomic indicators was positive for HDI and its HDI income and HDI education levels, as well as average household income per capita, but not significant ( $>0.05$ ). Regarding health indicators, there was a positive and significant correlation with public health expenditures per capita $(p<0.001)$ and mortality rate due to $\mathrm{CAD}(\mathrm{p}<0.001)$. The correlation with the number of medical consultations in per capita public health $(p=$ 0.296), and with the number of medical professionals per capita $(p=0.054)$, was not statistically significant. However, this last relation was within the limit of the significance assumed in this study, and, therefore,

TABLE 1. AVERAGE AND MEDIAN NUMBER OF HYPERTENSIVE PATIENTS REGISTERED IN SISHIPERDIA ACCORDING TO STRATIFICATION OF HIGH AND VERY HIGH RISK AND BRAZILIAN REGION. BRAZIL, 2013

\begin{tabular}{l|l|l|l|l}
$\begin{array}{l}\text { Risk for } \\
\text { cardiovascular } \\
\text { diseases }\end{array}$ & $\begin{array}{l}\text { Brazilian } \\
\text { region }\end{array}$ & Average & Median & $\mathrm{P}^{*}$ \\
\hline High & North & $29,997.57$ & $25,897.17$ & 0.002 \\
& Northeast & $98,502.02$ & $93,417.06$ & \\
& Southeast & $239,398.21$ & $243,308.37$ & \\
& South & $145,846.65$ & $143,939.10$ & \\
& Mid-West & $43,382.76$ & $50,275.47$ & \\
\hline Very high & North & $20,815.53$ & $14,342.09$ & 0.003 \\
& Northeast & $61,357.20$ & $56,005.12$ & \\
& Southeast & $197,992.15$ & $181,698.33$ & \\
& South & $101,462.00$ & $115,454.48$ & \\
& Mid-West & $29,427.12$ & $30,317.53$ & \\
\hline
\end{tabular}

Source: Prepared by the authors. *Kruskal-Wallis Test.

TABLE 2. MATRIX OF CORRELATION BETWEEN SOCIOECONOMIC AND HEALTH INDICATORS WITH THE NUMBER OF HYPERTENSIVE PEOPLE REGISTERED AT HIGH RISK. SISHIPERDIA, BRAZIL, 2013

\begin{tabular}{l|l|l|l} 
& $r$ & $r^{2}$ & $p$ \\
\hline HDI & 0.158 & 0.024 & 0.432 \\
\hline HDI income & 0.125 & 0.015 & 0.536 \\
\hline HDI education & 0.196 & 0.038 & 0.328 \\
\hline Survival at 60 years old & -0.475 & 0.225 & $0.012^{*}$ \\
\hline $\begin{array}{l}\text { Expenditures with public health } \\
\text { per capita }\end{array}$ & 0.926 & 0.857 & $<0.001^{*}$ \\
\hline $\begin{array}{l}\text { Average household income } \\
\text { per capita }\end{array}$ & 0.131 & 0.017 & 0.516 \\
\hline $\begin{array}{l}\text { SUS Admission } \\
\begin{array}{l}\text { Number of consultations in public } \\
\text { health per inhabitant }\end{array}\end{array}$ & 0.209 & 0.043 & 0.296 \\
\hline $\begin{array}{l}\text { Number of medical professionals } \\
\text { per inhabitant }\end{array}$ & 0.375 & 0.141 & 0.054 \\
\hline $\begin{array}{l}\text { Mortality rate per coronary artery } \\
\text { disease - CAD }\end{array}$ & 0.952 & 0.906 & $<0.001^{*}$ \\
\hline
\end{tabular}

Source: Prepared by the authors. *Significant at the level of $5 \%$. this result should be evaluated with caution. Negative and significant correlation was detected with survival at 60 years old $(p=0.012)$ (Table 2$)$. Regarding the determination factor between the variable "high-risk SAH registry" and the indicators, the following results were observed: with survival at 60 years old, this factor was $22.5 \%$; with expenditures on public health per capita, 85.7\%; number of medical professionals per inhabitant, $14.1 \%$; and with the mortality rate due to CAD, it was $90.6 \%$.

The number of hypertensives at very high risk correlated with socioeconomic indicators identified a positive correlation, not significant, with HDI, HDI income, HDI education and average household income per capita. In the analysis with health indicators, there was a positive and significant correlation with public health expenditures per capita $(\mathrm{p}<0.001)$, number of professionals per capita $(p=0.028)$, and mortality rate due to CAD ( $\mathrm{p}<0.001)$. The number of medical consultations in public health per capita $(p$ $=0.445$ ) obtained a nonsignificant correlation. There was a negative and significant correlation with survival at 60 years old $(p=0.032)$ (Table 3$)$. And, regarding the factor of determination between the outcome variable "very high risk SAH registry" and the indicators, the following results were identified: survival at 60 years old was $17.2 \%$; with public health expenditures per capita, 90.4\%; number of medical professionals per inhabitant, $17.9 \%$; and with the disease mortality rate due to CAD, this factor was $90.4 \%$.

TABLE 3. MATRIX OF CORRELATION BETWEEN SOCIOECONOMIC AND HEALTH INDICATORS WITH THE NUMBER OF HYPERTENSIVE PEOPLE REGISTERED AT VERY HIGH RISK. SISHIPERDIA, BRAZIL, 2013

\begin{tabular}{|c|c|c|c|}
\hline & r & $r^{2}$ & $p$ \\
\hline $\mathrm{HDI}$ & 0.209 & 0.044 & 0.296 \\
\hline HDI income & 0.181 & 0.033 & 0.365 \\
\hline HDI education & 0.230 & 0.053 & 0.248 \\
\hline Survival at 60 years old & -0.415 & 0.172 & $0.032^{*}$ \\
\hline $\begin{array}{l}\text { Expenditures with public health } \\
\text { per capita }\end{array}$ & 0.951 & 0.904 & $<0.001^{*}$ \\
\hline $\begin{array}{l}\text { Average household income } \\
\text { per capita }\end{array}$ & 0.186 & 0.035 & 0.354 \\
\hline SUS Admission & -0.159 & 0.025 & 0.429 \\
\hline $\begin{array}{l}\text { Number of consultations in public } \\
\text { health per inhabitant }\end{array}$ & 0.153 & 0.023 & 0.445 \\
\hline $\begin{array}{l}\text { Number of medical professionals } \\
\text { per inhabitant }\end{array}$ & 0.423 & 0.179 & $0.028^{*}$ \\
\hline $\begin{array}{l}\text { Mortality rate per coronary artery } \\
\text { disease - CAD }\end{array}$ & 0.951 & 0.904 & $<0.001^{*}$ \\
\hline
\end{tabular}

Source: Prepared by the authors. *Significant at the level of $5 \%$. 
Figure 1 shows the correlation between the number of people registered with very high-risk SAH and the number of deaths due to diseases of the circulatory system, for every 100,000 Brazilians $(r=0.904)$.

\section{DISCUSSION}

The median of SAH registries, both for the high risk and the very high risk strata, in the Brazilian regions were high. In the Brazilian and international scenario, SAH is the main risk factor for cerebrovascular disease, ischemic heart disease and for the global burden of diseases in men and women of all ages. It is the leading cause of preventable death in the world, responsible for $13 \%$ of deaths. It is estimated that the global prevalence of SAH will be $29 \%$ by 2025 , taking into account only population increase and age composition. This percentage equals approximately 1.56 billion people affected. In Latin America, SAH affects over a third of the population. ${ }^{6,20,21}$ In Brazil, in 2011, according to the study "Surveillance of risk factors and protection for chronic diseases by telephone survey" (Vigitel), $22.7 \%$ of individuals aged 18 years old reported a diagnosis of SAH. ${ }^{6}$

In the current study, it was observed that in most Brazilian states, about one-third of the hypertensive patients registered were stratified as high/very high risk. It was also found that the largest state population contingent did not necessarily correspond to a higher percentage of people allocated to these risk strata among the registered individuals. On the other hand, the highest medians of registries were obtained in the Southeast region, for all strata of risk, high and very high.

Epidemiological studies corroborate a higher frequency of SAH patients in the Southeast. ${ }^{6,9}$ However, because this work is a secondary data analysis, the largest number in the Southeast region may refer to factors such as the effectiveness of the hypertensive registry system and better access to public health services. In this way, undiagnosed fractions of SAH cases may persist, which tend to be reduced by expanding access to healthcare services and organizing care at the basic level. This same hypothesis may explain the higher frequency of SAH in the population of the Southeast and South regions, with an older population and with a greater structure of healthcare services, both in the public sector and in the private sector, for access to the medical diagnosis of $\mathrm{SAH} .{ }^{22}$

The results described, with regional differences, may be multifactorial, reflect socioeconomic situations, schooling, income, age distribution and access to healthcare services, resulting in a higher concentration of risk factors in certain regions. Social inequities and living conditions are the main barriers to the progress and improvement of the healthcare situation. And the recognition of these realities can be useful in the definition of healthcare priorities. ${ }^{23}$

Thus, the classic panorama of regional inequalities in Brazil mentioned in other studies is configures. $^{10,21}$ A research ${ }^{21}$ highlighted a group of eight federation units - seven states in the South/Southeast and the Federal District - with high levels of healthcare development, characterized by the best infrastructure of healthcare resources to provide specialized and more complex care. These units also have a greater coverage of Primary Health Care (PHC) and sanitation indicators are better. ${ }^{21}$ This fact indicates the close relationship between health and total expenditure on healthcare per capita and the need to prioritize public policies that overcome these inequities in order to guarantee the principle of healthcare universality in SUS. ${ }^{10,21}$

The results point to some challenges that need to be overcome and which point to the need for continuous investment in PHC, health promotion actions and the search for overcoming healthcare inequities. Government measures for access to medication, such as the implementation of the Popular Pharmacy Pro-

FIGURE 1. CORRELATION BETWEEN NUMBER OF HYPERTENSIVE PEOPLE REGISTERED AT VERY HIGH RISK WITH NUMBER OF DEATHS DUE TO DISEASES OF THE CIRCULATORY SYSTEM.

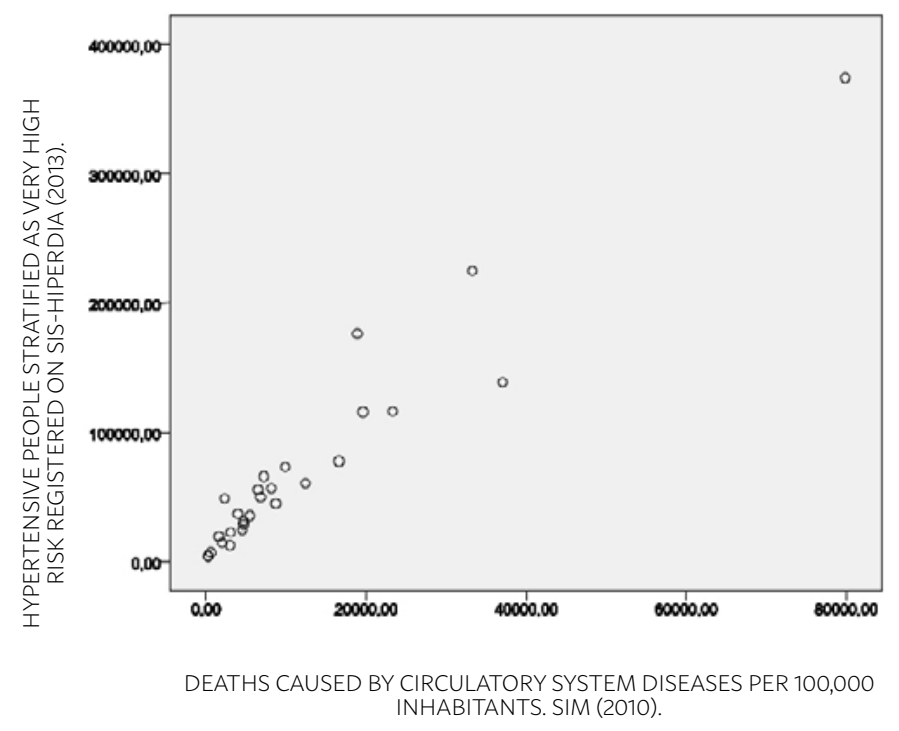


gram in Brazil, can be beneficial, as long as users do not lose their link with healthcare professionals and are guided and accountable for the care necessary to control the SAH. ${ }^{21}$ On the other hand, the increase in the prevalence of a morbid condition, which can be observed in the high prevalence of SAH in the Southeast, can be a positive indicator of access to services, diagnosis and/or reduction of lethality. ${ }^{24}$

It is worth mentioning that in some populations of the Amazon region, the prevalence of SAH is, today, equivalent to that found in medium to large cities. This region is distinguished by the consequences of the entry of its inhabitants into modern life. The use of industrialized foods, withdrawal from extractivism and reduction of physical activity were changes that led to alterations in blood pressure, a fact reported over a decade ago, but which is still important today since it repeats itself. The transition from the rural to the urban lifestyle leads to a higher cardiovascular risk and suggests that the environment played an important role in the relations presented. ${ }^{25}$

In this study, the significant correlation in the high and very high risk strata was present with the health indicator expenditure on public health per capita, with $85.7 \%$ of the largest public health expenditures being explained by the greater number of HAS of high risk and 90.4\% of expenditures explain the very high risk variation. Thus, the greater variation in public expenditure was better explained by the higher risk variable, that is, where there are more high-risk registries, there are higher public health expenditures per capita.

Thus, the implications of SAH in healthcare services and expenditures are also observed, as verified in the literature. ${ }^{24,26,27}$ In another study, ${ }^{24}$ the association with this disease and other NCDs was detected with increased hospitalization, in the use of healthcare services, the prevalence of medical consultations, and the risk of having been bedridden and of restricting activities. Moreover, it was found that the inequality of living conditions of the Brazilian adult population, evaluated by years of schooling and by affiliation to private healthcare plans, was associated with different prevalence of chronic conditions, where the higher were, in general, found in socially disadvantaged segments. ${ }^{24}$

In addition, renal dialysis expenditures, one of the consequences of $\mathrm{SAH}$, increased from approximately BRL 600 million in 2000 to BRL 1.7 billion in $2009 .^{26,27}$ Faced with this problem, in early 2011, the
Ministry of Health expanded the Popular Pharmacy Program, which now offers free basic medicines for diabetes mellitus and SAH, as well as drugs for other chronic diseases, with discounts of up to $90 \%$ - funded by government power. ${ }^{26,27}$

It is noted that the impact that health problems have on patients with SAH is very intense, and can lead to death or often impair their quality of life, which makes it a priority to avoid such outcomes. ${ }^{28}$ The worsening of disease when diagnosed at advanced stages can cause secondary injuries such as kidney and heart problems; a burden on society with the increase of chronic patients and loss of work force, with leaves and retirements motivated by the incapacity generated by the disease, in addition to the expenses with healthcare services and medication, among others. ${ }^{29}$

It is, therefore, a worrying reality that highlights the need for a better strategic planning of intervention, with the purpose of promoting changes in the lifestyle of at-risk groups. ${ }^{30}$ Thus, a concomitant change to the allocation of resources, in relative terms, of hospital treatment and high technology for health promotion and prevention is needed to increase budget support and central coordination for prevention and care of SAH. ${ }^{27}$

Regarding the mortality rate due to $\mathrm{CAD}$, there was a strong positive correlation with the number of registries at high and very high risk, and the variation of high risk registries can be explained in $90.6 \%$, and in the very high, in $90.4 \%$. It should be noted the limitations of this indicator. Since the specific mortality rate is not standardized by age, it is subject to the influence of variations in the age composition of the population, which requires caution in comparisons between geographic areas. However, positive correlation was expected and plausible in the literature. , $, 2,5,27,31,32^{2}$

Furthermore, in the present study, in the analysis with health indicators, negative correlation was detected with survival at 60 years old for high and very high risk hypertensive patients' registry. This means that sites with more hypertensive registries, at greater risk, have a linear tendency of fewer people reaching the age of 60, the elderly age group in Brazil.

This result is explained in the literature ${ }^{1,31,32}$ : demographic aging, urbanization and globalization, as well as the changes in populations' lifestyle, due to these phenomena, have impacted the increase of SAH and other NCDs and, consequently, worldwide mortality. This also implies more patients with SAH in situa- 
tions of high/very high cardiovascular risk, with more complications, delicate state of health and, therefore, with greater exposure to the risk of death. There is a concentration of deaths due to $\mathrm{SAH}$, as well as other NCDs, in low and middle-income countries, where there are high numbers of early deaths, especially among people under 60 years of age. ${ }^{1,31,32}$

In view of this reality, high mortality due to CAD and early deaths, it is worth noting that a survey covering the states of Rio de Janeiro, São Paulo, Rio Grande do Sul and its capital cities, ${ }^{33}$ which correlated mortality rates by CAD with socioeconomic indicators collected since 1949, revealed that in the past three decades there was a significant reduction in all-cause mortality. This reduction was mainly due to a decrease in mortality due to CAD. The decrease in this mortality was preceded by an improvement in socioeconomic indicators, signalling the importance of improving the living conditions of the population in order to reduce cardiovascular mortality. ${ }^{33}$

The aforementioned study ${ }^{33}$ fuels the expectation that the sufficient supply of SUS quality services can significantly reduce social inequalities in the risks of becoming ill and dying. Thus, actions aimed at promoting better living conditions and healthy behaviours are privileged strategies to reduce social inequality in terms of morbidity and mortality. ${ }^{24} \mathrm{An}$ other study ${ }^{34}$ found that individuals with a diagnosis of SAH were more likely to seek healthcare services and were advised to change their behaviours in relation to diet and smoking. It has also been identified a greater chance of survival of those who report less risk behaviour, since positive changes may delay or avoid the appearance of complications commonly associated with SAH mortality. ${ }^{34}$

Being in the hypertensive condition with high/ very high risk did not establish a linear association with more medical consultations in the public sector. However, it is known that, in the healthcare system, there is a need for more consultation for the user in that situation, to provide to proper follow-up. On the other hand, in relation to the correlation with the number of doctors per inhabitants, this was positive and significant. Given this result, it is plausible to assume that where there are more physicians there is greater access to the diagnosis and, thus, hypertensive patients classified in the risk strata analysed in this study are identified. In addition, generally, where there are people with more health complications, more healthcare professionals are required.
Such demand may have an impact on the increase in expenditures with services, physicians and other healthcare professionals, and on the need for medical professionals to be properly qualified to provide appropriate care to the hypertensive patient. ${ }^{34,35}$

Therefore, it is suggested the development of healthcare actions that promote the access of hypertensive users to healthcare professionals and services, who should offer comprehensive care. This optimizes adherence to treatment and control of blood pressure, with consequent improvement in quality of life and a positive impact on reducing morbidity and mortality. ${ }^{35}$ Thus, it is evident the need to carry out policies and practices of harm reduction and promotion of health. To this end, the services of the Family Healthcare Strategy (ESF) should be highlighted, in which the early intake of hypertensive patients should occur, in order to institute appropriate therapeutic measures for each situation, preventing complications and comorbidities. ${ }^{2,4}$

Regarding the limitations of this study, there is a possibility of ecological bias, that is, failure of the ecological associations to reflect the biological effect at the individual level, pertinent to any study of ecological design. Also, the secondary data used are susceptible to errors, for example underreporting of hypertensive registries or technical failure in the stratification of risks for SAH. Therefore, the analyses should consider the limitations of coverage and quality of information of the HiperDia system and other sources consulted in the current research.

\section{CONCLUSION}

The correlation between hypertensive patients with high/very high risk for cardiovascular diseases and socioeconomic and health indicators showed that where there are more registries with serious risk, there is more expenditure, per capita, in public health; fewer people reach the age 60 and more people die from diseases of the circulatory system. The increase in the number of physicians was significant for the very high risk strata.

In this sense, the SAH has a direct impact on life expectancy and also on the economic context, since, especially when it develops to high and very high risk of cardiovascular diseases, it generates more expenses in healthcare and requires more professionals, burdening the public health system. In this way, healthcare professionals and managers should mon- 
itor SAH cases in order to ensure the effectiveness and consolidation of public policies aimed at prevention and harm reduction, in order to promote health and savings in public health expenditures. Improvements in the quality of the national information system are also necessary to allow the limitations found in the current research to be overcome by new studies, which may provide a more accurate knowledge of the problem investigated.
Institution where the work was carried out: State University of Montes Claros, Montes Claros, MG, Brazil.

Area: Public Health

We declare that there was no conflict of interest in the conception of this work.

Financing: Minas Gerais State Agency for Research and Development (Fapemig) - Process CDSAPQ-00404-13

\section{RESUMO}

OBJETIVO: Correlacionar o número de cadastros de hipertensos com risco alto e muito alto para doenças cardiovasculares com os indicadores socioeconômicos e de saúde.

MÉTOdos: Estudo ecológico realizado a partir do Sistema Nacional de Cadastro de Hipertensão e Diabetes (SisHiperDia). A variável "hipertensos com risco alto e muito alto" foi correlacionada ao Índice de Desenvolvimento Humano, gastos com ações e serviços de saúde, renda média domiciliar per capita, renda municipal per capita, número de internações hospitalares no SUS, número de consultas médicas no SUS e mortalidade específica por doenças do aparelho circulatório, considerando as 27 unidades federativas do Brasil. Os dados foram processados no software IBM Statistical Package for the Social Sciences (SPSS) Statistics, versão 22.0Ò. A análise estatística considerou o nível de significância $p<0,05$.

RESULTADOS: Estados brasileiros com mais cadastros de hipertensos em riscos alto/muito alto gastam mais na saúde pública, menos pessoas alcançam a faixa etária idosa e há mais mortes por doenças do aparelho circulatório $(p<0,05)$. O estrato de risco muito alto correlacionou com mais médicos por habitantes $(p<0,05)$.

CONCLUSÃo: A hipertensão arterial sistêmica impacta diretamente a expectativa de vida e também o contexto econômico, pois, quando evolui para risco alto e muito alto, para as doenças cardiovasculares, gera mais gastos em saúde e demanda mais profissionais, onerando o sistema público de saúde. É necessário monitoramento, em busca da consolidação das políticas públicas de promoção da saúde dos hipertensos.

PALAVRAS-CHAVE: Hipertensão. Saúde pública. Brasil. Indicadores econômicos. Indicadores sociais.

\section{REFERENCES}

1. Brasil. Ministério da Saúde. Secretaria de Vigilância em Saúde. Departamento de Análise de Situação de Saúde. Plano de ações estratégicas para o enfrentamento das doenças crônicas não transmissíveis (DCNT) no Brasil 2011-2022. Brasília: Ministério da Saúde; 2011.

2. Brasil. Ministério da Saúde. Secretaria de Atenção à Saúde. Departamento de Atenção Básica. Estratégias para o cuidado da pessoa com doença crônica: hipertensão arterial sistêmica. Brasília: Ministério da Saúde; 2013.

3. Ribeiro AG, Ribeiro SM, Dias CM, Ribeiro AQ, Castro FA, Suárez-Varela $M M$, et al. Non-pharmacological treatment of hypertension in primary health care: a comparative clinical trial of two education strategies in health and nutrition. BMC Public Health. 2011;11:637.

4. Costa JMBS, Silva MRF, Carvalho EF. Avaliação da implantação da atenção à hipertensão arterial pelas equipes de Saúde da Família do município do Recife (PE, Brasil). Ciênc Saúde Colet. 2011;16(2):623-33.

5. World Health Organization (WHO). A global brief on hypertension. Genebra: WHO; 2013.

6. Brasil. Ministério da Saúde. Secretaria de Vigilância em Saúde. Agência Nacional de Saúde Suplementar. Vigitel Brasil 2011: vigilância de fatores de risco e proteção para doenças crônicas por inquérito telefônico. Rio de Janeiro: Ministério da Saúde; 2012.

7. Lessa I. Systemic arterial hypertension in Brazil: temporal trends. Cad Saude Publica. 2010;26(8):1470.

8. De Sá CA, Corralo VS, Fachineto S, Schmidt CL, Cezar MA, Ribeiro CG. Obesidade, condição socioeconômica e hipertensão arterial no Extremo Oeste de Santa Catarina. Rev Salud Pública. 2014;16(2):184-94.
9. Piccini RX, Facchini LA, Tomasi E, Siqueira FV, Silveira DS, Thumé E, et al. Promotion, prevention and arterial hypertension care in Brazil. Rev Saude Publica. 2012;46(3):543-50.

10. Brevidelli MM, Freitas FCG. Estudo ecológico sobre o desenvolvimento da saúde no Brasil. Ciênc Saúde Colet. 2012;17(9):2471-80.

11. Brasil. Ministério da Saúde. Departamento de Informática do SUS (DATASUS). Sistema de Cadastro e Acompanhamento de Hipertensão e Diabetes. SISHIPERDIA. 2013. Apresentação. Relatório de Indicadores das Situações de Agravos. [cited 2 ago. 2013]. Available from: http://hiperdia. datasus.gov.br

12. PNUD. Programa das Nações Unidas para o Desenvolvimento. Atlas de Desenvolvimento Humano no Brasil 2013. [cited 2 ago. 2013]. Available from: http://www.pnud.org.br/IDH/Atlas2013.aspx?indiceAccordion=1\&li=liAtlas2013

13. Brasil. Ministério da Saúde. Rede interagencial de informações para a saúde. RISPA. Gastos com ações e serviços públicos de saúde per capita. 2010. [cited 2 ago. 2013]. Available from: http://tabnet.datasus.gov.br/ cgi/deftohtm.exe?idb2011/e0602.def

14. Brasil. Instituto de Geografia e Estatística - IBGE. Síntese de indicadores sociais: uma análise das condições de vida da população brasileira 2012. Rio de Janeiro: IBGE; 2012.

15. PNUD. Programa das Nações Unidas para o Desenvolvimento. PNUD; 2003. [cited 5 nov. 2011]. Available from: http://www.pnud.org.br/atlas/textos_analiticos/index.php 
16. Brasil. Ministério da Saúde/DATASUS. Sistema de Informações Hospitalares do SUS -SIH/SUS. 2010. [cited 12 ago. 2013]. Available from: http:// www2.datasus.gov.br/DATASUS/index.php

17. Brasil. Ministério da Saúde. Rede interagencial de informações para a saúde. RISPA. Número de consultas médicas (SUS) por habitante. 2010. [cited 12 ago. 2013]. Available from: http://tabnet.datasus.gov.br/cgi/ deftohtm.exe?idb2011/f01.def

18. Brasil. Ministério da Saúde. Rede interagencial de informações para a saúde. RISPA. Número de profissionais de saúde por habitante. 2010 [cited 12 ago. 2013]. Available from: http://tabnet.datasus.gov.br/cgi/ deftohtm.exe?idb2009/e01.def

19. Brasil. Ministério da Saúde. Rede interagencial de informações para a saúde. RISPA. Taxa de mortalidade específica por doenças do aparelho circulatório. 2010. [cited 2 ago. 2013]. Available from:http://tabnet.datasus.gov.br/cgi/deftohtm.exe?idb2009/c08.def

20. Lim SS, Vos T, Flaxman AD, Danaei G, Shibuya K, Adair-Rohani H, et al. A comparative risk assessment of burden of disease and injury attributable to 67 risk factors and risk factor clusters in 21 regions, 1990-2010: a systematic analysis for the Global Burden of Disease Study 2010. Lancet. 2012;380(9859):2224-60.

21. Ferreira RA, Barreto SM, Giatti L. Hipertensão arterial referida e utilização de medicamentos de uso contínuo no Brasil: um estudo de base populacional. Cad Saúde Pública. 2014;30(4):815-26.

22. Andrade SS, Malta DC, Iser BM, Sampaio PC, Moura L. Prevalence of self-reported arterial hypertension in Brazilian capitals in 2011 and analysis of its trends in the period between 2006 and 2011. Rev Bras Epidemiol. 2014;17(Suppl 1):215-26.

23. Malta DC, Berna RI, Almeida MC, Ishitani LH, Girodo AM, Paixão LM, et al. Inequities in intraurban areas in the distribution of risk factors for non communicable diseases, Belo Horizonte, 2010. Rev Bras Epidemiol. 2014;17(3):629-41.

24. Barros MBA, Francisco PMSB, Zanchetta LM, César CLG. Tendências das desigualdades sociais e demográficas an prevalência de doenças crônicas no Brasil, PNAD: 2003-2008. Ciênc Saúde Colet. 2011;16(9):3755-68.

25. Tavares RS, Silva DMGV, Dal Sasso GTM, Padilha MICS, Santos CRM. Cardiovascular risk factors: the study included hypertensive people in a popular neighborhood in the Amazon region. Cienc Cuid Saude. 2014;13(1):4-11.

26. Victora CG, Barreto ML, do Carmo Leal M, Monteiro CA, Schmidt MI, Paim J, et al; Lancet Brazil Series Working Group. Health conditions and health-policy innovations in Brazil: the way forward. Lancet. 2011;377(9782):2042-53.

27. Schmidt MI, Duncan BB, Azevedo e Silva G, Menezes AM, Monteiro CA, Barreto SM, et al. Doenças crônicas não transmissíveis no Brasil: carga e desafios atuais. Lancet. 2011;377(9781):61-74.

28. Boing AC, Boing AF. Hipertensão arterial sistêmica: o que nos dizem os sistemas brasileiros de cadastramentos e informações em saúde. Rev Bras Hipertens. 2007;14(2):84-8.

29. Salcedo-Barrientos DM, Siqueira EFG, Egry EY. Determinantes sociais e hipertensão arterial: um desafio an saúde coletiva. Avances Enfermería. 2013;31(1):72-86.

30. Nascimento ES, Castelo Branco MPF, Moreira AKF, Hazime FA. Estratificação do risco cardiovascular global em hipertensos atendidos numa unidade de saúde da família de Parnaíba, Piauí. Rev Bras Promoç Saúde. 2012;25(3):287-94.

31. World Health Organization - WHO. Global status report on noncommunicable diseases 2010. Geneva:WHO, 2011. [cited 9 set. 2014]. Available from: <http://whqlibdoc.who.int/ publications/2011/9789240686458_ eng.pdf>

32. Alwan A, Maclean DR, Riley LM, d'Espaignet ET, Mathers CD, Stevens $\mathrm{GA}$, et al. Monitoring and surveillance of chronic non-communicable diseases: progress and capacity in high-burden countries. Lancet. 2010;376(9755):1861-8.

33. Soares GP, Brum JD, Oliveira GM, Klein CH, Souza e Silva NA. Evolution of socioeconomic indicators and cardiovascular mortality in three Brazilian states. Arq Bras Cardiol. 2013;100(2):147-56.

34. Barreto SM, Figueiredo RC. Chronic diseases, self-perceived health status and health risk behaviours: gender differences. Rev Saude Publica. 2009;43(Suppl 2):38-47.

35. Medeiros ARC, Araújo YB, Vianna RPT, Moraes RM. Modelo de suporte à decisão aplicado à identificação de indivíduos não aderentes ao tratamento anti-hipertensivo. Saúde Debate. 2014;38(100):104-18. 